\title{
RAYMUNDO FAORO, NOSSO AMIGO
}

\section{MARIA VICTORIA DE MESQUITA BENEVIDES}

Modéstia à parte, Raymundo Faoro foi um dos nossos. O consagrado autor de Os Donos do Poder era, sim, "da casa": mestre, crítico, conselheiro, colaborador, amigo de todos nós, os pais (e mães!) fundadores e os continuadores do CEDEC.

Pouco presente em pessoa, era uma referência constante; o grande historiador, jurista e sociólogo, mas também o publicista notável, que sempre acompanhou, com sua pena certeira e suas intervenções públicas, a vida política da nação. É bem conhecida sua brilhante atuação quando presidente do Conselho Federal da OAB (1977-1979). Aliás, a OAB adquiriu um prestígio extraordinário, como fonte e voz da sociedade civil, graças a ele. Tornouse um dos principais representantes dos que lutaram contra a ditadura, sendo interlocutor dos políticos e dos militares, que nele reconheceram um adversário lúcido, corajoso e livre de qualquer projeto político pessoal. Sempre ficou claro, para todos que o conheceram, sua completa falta de ambição para cargos e honrarias. É importante destacar este dado de sua personalidade, pois não foram poucos os que atribuíram ao seu dinamismo à frente da $\mathrm{OAB}$ objetivos políticos menos nobres, como ser nomeado ministro da Justiça ou membro do STF num futuro governo democrático. Os fatos provam que ele nada quis, nem abandonou suas trincheiras de luta contra os arrivistas da "transição transada".

Quando Luiz Inácio da Silva foi à sua casa convidá-lo para ser vice (campanha de 1989), Raymundo recebeu-o de braços abertos e adega fidalga (gostava muito do líder petista, com quem manteve relações de mútua admiração e amizade até o fim). Mas ponderou: "Lula, sou um homem preguiçoso e amante das boas coisas da vida. Aceitaria, de bom grado, uma embaixada em Viena...desde que vitalícia".

Apesar de participar, junto com Mino Carta, seu fraternal amigo, das revistas IstoÉ/Senhor, Carta Capital e do excelente e efêmero Jornal da 
República, era pouco presente em São Paulo. Detestava deixar o Rio de Janeiro, onde morava - com fino gosto (e entre montanhas de livros e vídeos de teatro) -, debaixo do Cristo Redentor, com quem, dizia, muitas vezes "acertava as contas", o coração pesado de ira et studio. O bairro chama-se Cosme Velho, escolhido como se Raymundo Faoro quisesse também os ares bucólicos de seu querido Machado, sobre o qual escreveu a obra prima Machado de Assis: A Pirâmide e o Trapézio (livro pouco lembrado, o que é uma lástima). Aliás, como o velho bruxo, Raymundo tinha o horror de ser "medalhão". Aceitava nossos convites, no CEDEC ou na USP, mas avisava: estão proibidas as louvações.

A ele o CEDEC muito deve. Seu empenho entusiasmado garantiu, por exemplo, o primeiro grande Seminário da Abertura no Brasil, em junho de 1979, com apoio da OAB e patrocínio da Fundação Ford. Organização conjunta CEDEC-CEBRAP (sob a minha aflita e orgulhosa coordenação, desculpem-me a vaidade) e realizado na PUC da reitora Nadir Kfouri, este superseminário Direito, Cidadania e Participação (depois publicado pela editora T. A. Queiroz) reuniu intelectuais e políticos de todo o país e dos EUA, todos comprometidos com a instauração de um Estado de Direito Democrático. Foi um grande sucesso de público e de imprensa e um marco decisivo na história do CEDEC. A partir de então, nosso pequeno Centro consolidou foros de credibilidade para várias empreitadas, conseguindo apoios acadêmicos e financeiros no país e no exterior. Daí também se consolidaram projetos relevantes para a identidade do Centro, em torno da cidadania, dos direitos humanos, da reforma política, dos movimentos sociais.

Raymundo Faoro colaborou em diversas outras ocasiões com o CEDEC, ora como avalista de projetos, ora como crítico interlocutor em seminários ou textos, dentre os quais destaco os debates sobre a Constituinte, que queríamos nacional, livre e soberana. Foi acompanhando esses debates que Raymundo Faoro escreveu, convidado por Caio Graco, o belo ensaio Assembléia Constituinte, a legitimidade recuperada (1986).

Participou, igualmente, de nossas publicações; destaco um original artigo sobre liberdade de imprensa em nossa primeira revista, a Revista de Cultura e Política, e uma instigante entrevista para Lua Nova ("A democracia que queremos", no número 5, de 1985).

Apreciava, com evidente espírito de argumentação clássica, o debate intelectual de alto nível e assim integrou bancas examinadoras na Universidade: de Carlos Guilherme Mota, de Gabriel Cohn, de Paulo Sérgio Pinheiro, de Marco Aurélio Nogueira e de Kátia Mendonça, entre outros. Weberiano ilustre, da tese de Gabriel gostava de dizer que podia figurar entre o que de melhor se escreveu sobre Max Weber... na Alemanha! (Estava 
apalavrado para participar da banca de Marco Aurélio Garcia, mas, como se sabe, a política vem adiando a defesa do Marco).

Sua figura imponente de origem vêneta (quase dois metros de altura) e o tom muito grave da voz podiam intimidar o recém-chegado. Mas logo se percebia que a imensa cultura não atrapalhava o formidável wit, o senso de humor inigualável, a começar pelo riso sobre si próprio: "Não tenho a elegância do patriciado paulista, sou um simples gaúcho de Vacaria. Aprendi alemão nos clubes masculinos de Porto Alegre, inglês porque me deslumbrei com Shakespeare, sobretudo as peças políticas, e francês... bem, francês aprendi com as fábulas de La Fontaine, e falo como um animal".

Por iniciativa de Carlos Guilherme Mota foi o primeiro professor visitante do IEA da USP, onde desenvolveu um estudo original publicado com o título Existe um pensamento político brasileiro? Gostava do ambiente e dos colegas, mas me dizia, docemente irônico, para eu não me preocupar pois o CEDEC estaria sempre em primeiro lugar.

É difícil encontrar um personagem de tal envergadura - tão "varão da República" - e que seja, ao mesmo tempo, tão simples e generoso. Isso mesmo, o ilustre Raymundo Faoro foi, sem pieguice, um homem bom. Um homem de generosidade pessoal e intelectual, fortiter in re, suaviter in modo. Antônio Candido disse, certa vez, referindo-se a Fernando de Azevedo, que um grande intelectual não será, necessariamente, um grande homem público, e que seu mestre Azevedo fora ambos. Podemos dizer o mesmo de nosso mestre e amigo Raymundo Faoro.

Raymundo Faoro foi um gaúcho-italiano à moda antiga, que não temia uma boa briga nem cultivar os inevitáveis inimigos, mas mantinha sempre a exigência de honra, lealdade e caráter que, segundo ele, bebera no leite materno (as histórias que contava sobre a mãe Maria Luiza dariam um romance de Érico Veríssimo). Pode ter sido, por isso, mal compreendido por alguns adeptos da modernidade deslumbrada e do "politicamente correto". Tudo isso é bobagem. Raymundo Faoro foi, simplesmente, um homem íntegro, inteligente e encantador.

Uma saudade danada.

MARIA VICTORIA de MESQUITA BENEVIDES é ... Modéstia à parte, Maria Victoria é uma das nossas. 


\section{RESUMOS/ABSTRACTS}

\section{RAYMUNDO FAORO, NOSSO AMIGO}

MARIA VICTORIA DE MESQUITA BENEVIDES

Fundadora e participante de primeira hora do CEDEC evoca a figura do grande intelectual morto recentemente.

Palavra-chave: Faoro, Raymundo.

\section{RAYMUNDO FAORO, OUR FRIEND}

A founder and longtime member of CEDEC evokes the figure of the recently deceased great intellectual.

Keyword: Faoro, Raymundo 